\title{
THE RELATIONSHIP BETWEEN COST MANAGEMENT AND FINANCIAL PERFORMANCE IN TELECOM COMPANIES; TURKEY, EGYPT \& SAUDI ARABIA
}

\author{
DOI: 10.17261/Pressacademia.2021.... \\ PAP- V.14-2021(26)-p.115-116
}

\section{Samatar Muse}

Istancul Commerce University, International Finance Department, Istanbul, Turkey. Samata.muse@istanbulticaret.edu.tr, ORCID: 0000-0003-3738-9382

\section{To cite this document}

Muse, S., (2021). The relationship between cost management and financial performance in Telecom Comapines; Turkey, Egypt \& Saudi Arabia.PressAcademia Procedia (PAP), 14, 115-116.

Permanent link to this document: $h$ ttp://doi.org/10.17261/Pressacademia.2021.1500

Copyright: Published by PressAcademia and limited licensed re-use rights only.

\begin{abstract}
Purpose- The purpose of this study is to asses the relationship between cost management and financial performance of three telecommunication companies in Turkey, Egypt and Saudi Arabia on publickly trading companies on stock exchanges. Telecommunication companies are somehow struggling in attaining financial performance though issues of cost management remain underdeveloped as the cost analysis, budgeting, cost monitoring, and cost evaluations are poorly prevailing. This study distinguishes itself from the majority of the literature that it focuses on analyzing the cost trend, financial performance and the effect of cost management on financial performance of the companies.

Methodology- In the study, the analysis of data is determined using ratio analysis to establish the trend of cost management and financial performance that will be assessed in the financial statement of income and balance sheets. The financial performance is determined by using gross margin, return on assets, operating and net profit margin. While to attain the effect between cost management and financial performance of the companies, regression analysis was employed, so the operating costs were taken as cost management and the sales taken as financial performance.

Findings- The analysis reveals that the cost management for Egypt and Turkey telecom companies were very poor based on their results of current ratio, acid test ratio and net working capital to total assets ratio, while Saudi Arabia telecom company's cost management was way better compared to other two companies. Additionally, the financial performance analysis (gross margin, net profit margin, operating profit margin and return on assets) indicated a promising and positive results for all the companies except Egypt telecom company which encountered a disappointing finding. According to the results of regression analysis of the companies, the cost management has a significant contribution to the financial performances of the companies, as cost management has more than $78 \%$ effect on all the companies' financial performances, while their $p$-value are in a permissible range.

Conclusion- based upon the Findings it may be concluded that Turkey Telecom Company's cost management is poorly oriented; there is need for development of a scale for the effective financial performance of the company and in order to the keep the company's liabilities under control, the management should pay off the creditors quickly and reduce the repayment terms on the loans. Moreover, Egypt Telecom company needs to venture into the financial performance of the company by developing up avenues necessary for the development of the financial performance such as improving the business attractiveness and expanding its customers base. Lastly, the Saudi Telecom Company's cost management and financial performance analysis seem to be fairly good as all the results indicated a propitious finding, but the researcher suggests that the company should be mindful to the cost unit because its solely accountable for supplying the company's cost evaluation information
\end{abstract}

Keywords: Cost management, financial performance,Telecommunication companies, Financial analysis Turkey, Egypt, Saudi Arabia. JEL Codes: F40, F44, F47, H68, M16

\section{REFERENCES}

Adesina OT, Ikhu - Omoregbe S, Aboaba KO; Accounting information and profit planning: the case of Nigeria listed manufacturing companies. European Journal of accounting auditing and Finance Research, 2015; 3(4):86- 97.

Akeem, L. B. (2017). Effect of Cost Control and Cost Reduction Techniques in Organizational Performance. International Business and Management, 14 (3), 19-26.

Akenbor CO and Okoye El (2017). The Adoption of Strategic Management Accounting in Nigerian Manufacturing Firms an International Journal of Arts and Humanities Bahir Dar, Ethiopia, 2012; 1 (3):270-287 
Barth T. (2013). Financial performance and outreach: a global analysis of leading microbanks", Economic Journal, 117(517): F107-F133

Block, B. S., and Hirt, G. A., (2012), Foundation of Financial Management, 6th Ed, -USA. Pg 144-179

Botín, J.A., \&Verara, M.A. 2015. "A Cost Management Model for Economic Sustainability and Continuous Improvement of Mining Operations." Resources Policy 46: 212-218

Bryan, D.B. 2017. “Organized Labor, Audit Quality, and Internal Control.” Advances in Accounting 36: 11-26

Chong, H.C., Ramayah, T and Subramaniam, C. (2018). "The Relationship Between Critical Success Factors, Internal control and Safety Performance in the Malaysian Manufacturing Sector." Safety Science 104: 179-188

Dauda YA, Akingbade WA and Akinlabi HB (2016). Strategic Management Practice and Corporate Performance of Selected Small Business Enterprises in Lagos Metropolis. International Journal of Business and Management, 2010; 5(11):97 - 105

Gichunge EM (2016). The Effect of Formal Strategic management on Organizational Performance: A Study of Selected medium sized Manufacturing Enterprises in Nairobi, Kenya. Ph.D Dissertation.

Henri, Jean-François, Boiral, O., \& Roy, Marie-Josèe. 2016. "Strategic Cost Management and Performance: The Case of Environment Costs." The British Accounting Review 48: 269- 282.

Hussin, M.R.A., Alias, R.A., \& Ismail, K. 2013. "An Action Research Approach for the Development of Cost Management Skills Training Program Among the Owners of Small and Medium Enterprises (SMEs) In Malaysia." Procedia-Social and Behavioral Sciences

91: $515-521$

Kelly, K., \& Tan, Hun-Tong. 2017. "Mandatory Management Disclosure and Mandatory Independent Audit of Internal control: Evidence of Configure Information Processing by Invertors." Accounting, Organizations and Society 56: 1-20.

Kren, L. (2010). Budgeting participation and managerial performance: The impact of information and Environment volatility, The Accounting Review, 67, 511-526.

Lougee, B.A., \& Marquardt, C.A. (2014). "Earnings Informativeness and Strategic Disclosure: An Empirical Examination of "Pro Forma" Earnings." The Accounting Review 79(3): 769-795

Muogbo US (2018). The Impact of Strategic Management on Organizational Growth and development: A Study of Selected Manufacturing Firms in Anambra State. IOSR Journal of Business and Management; 7(1):24-32 